\title{
What determines the growth of micro firms in the euro area?
}

\author{
Sophia Dimelis ${ }^{1}$ Ioannis Giotopoulos ${ }^{2 *} \cdot$ Helen Louri ${ }^{3,4}$ \\ ${ }^{1}$ Athens University of Economics and Business, Department of Informatics, Greece \\ ${ }^{2}$ University of Peloponnese, School of Economy, Management \& Informatics, Department of Economics, Greece \\ ${ }^{3}$ Athens University of Economics and Business, Department of Economics, Greece \\ ${ }^{4}$ London School of Economics, EI/HO, UK
}

Received: 14 July 2016

Revised: 22 October 2016

Accepted: 24 October 2016

\begin{abstract}
This paper explores the diverging impact of country- and firm-specific factors on the growth of micro firms in the euro area (2005-2011) along different growth quantiles. While bank credit and firm sales seem to be important for all size groups and quantiles, micro firms are found to be particularly vulnerable to country-specific conditions, especially financial stability, country risk, banking concentration and post-crisis location in the European periphery, the most exposed ones being those with the slowest growth.
\end{abstract}

Keywords: micro firm growth; Euro area periphery; bank credit; banking concentration; panel quantile regressions.

JEL Classification Codes: L10, L25, E51

\section{Introduction}

Firm growth has been severely affected in post-crisis euro area. While micro and larger firms have followed the same growth path until 2008 (6.8\% annually in our sample), they diverged in the post-crisis period (Figure 1). ${ }^{1}$ Micro firms, being particularly important for their large numbers and the job creation potential, face a number of barriers in their effort to increase size and achieve high-growth rates (e.g. Coad and Tamvada, 2012; Lee, 2014). Moreover, micro firms seem to find it more difficult to recover from the crisis and start growing again. In this respect, this paper addresses the following research questions: Which factors are obstructing or facilitating the growth of micro firms? Is it mostly inherent firm characteristics such as financial

\footnotetext{
*Corresponding author. E-mail: giotopoulos@uop.gr.

Citation: Dimelis, S., Giotopoulos, I. and Louri, H. (2016) What determines the growth of micro firms in the euro area?, Economics and Business Letters, 5(4), 145-151.

${ }^{1}$ For micro firms we follow the definition provided by the European Commission (2003), i.e. firms with sales of less than $€ 2$ million. All other size groups (small, medium and large firms) are considered in our empirical analysis as larger (or non-micro) firms. The reason we classify them together is on the one hand the limited number of available observations and on the other our deliberate focus on the micro firms (vs. the rest).
} 
health and product dynamism or are there country-specific conditions which are not growth inducing?

Figure 1. Annual growth rates of 1767 micro and 308 larger firms in the euro area.

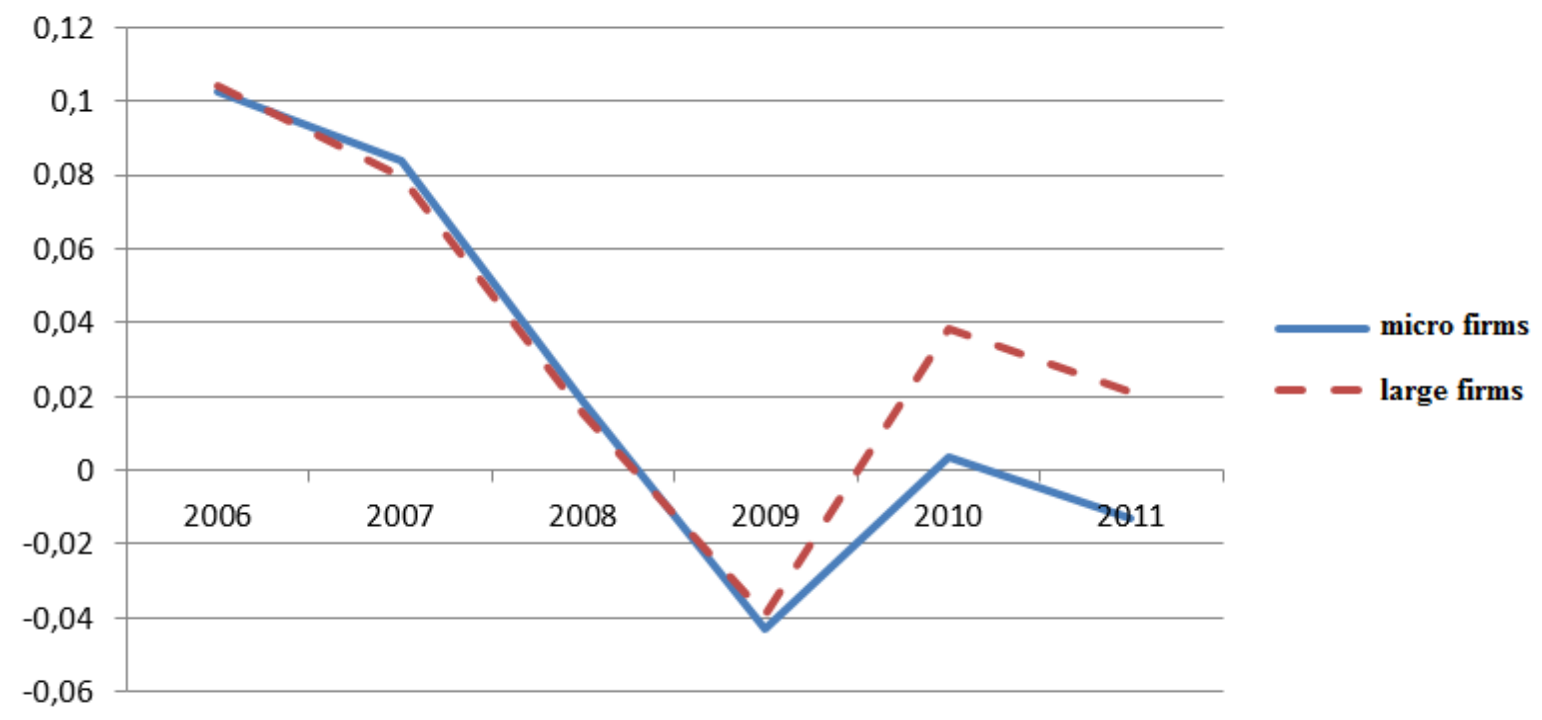

The fragmentation of financial and risk conditions in the euro area post-crisis poses a crucial obstacle to the growth potential especially for SMEs, as they are heavily dependent on bank credit and capital cost (Beck and Demirgüç-Kunt, 2006; ECB, 2013). Consistent evidence exists that the global credit crisis of 2008-9 led firms, particularly SMEs in Europe, to postpone or even cancel their investment plans leading to negative growth prospects (Campello et al., 2010; Peric and Vitezic, 2016).

Still, we are lacking a more complete empirical explanation of micro firm vulnerability which could provide specific directions for effective policy interventions. The present paper intends to fill this void by examining the impact of country- and firm-specific factors on firm growth for micro and larger firms with fast and slow growth events. Emphasis is put on the location effect of euro-area periphery, especially in the post-crisis years.

The paper is laid out as follows: section 2 describes the data and the methodology used; section 3 presents and discusses the main results of the empirical analysis; and section 4 concludes and provides some policy implications.

\section{Data and method}

This study uses longitudinal panel data of 2075 listed firms operating in the 17 countries of the euro area during the period 2005-2011, i.e. comprising three years before and three years after the crisis of 2008. Firm data were retrieved from the WorldScope Database (included in Datastream) which contains annual balance-sheets of quoted firms. Only firms fulfilling consistent selection criteria of time and information continuity were included. We split our sample in micro and larger firms using as criterion their initial (2005) sales (see fn 1). Thus, 1767 firms are classified as micro firms (with sales of less than $€ 2$ million), while 308 firms are classified as larger (than micro).

Firm growth is the dependent variable measured by the difference of the natural logarithm of sales in two subsequent years. The independent variables include firm-specific variables from the same database, as well as country financial characteristics retrieved from the ECB (bank credit change, banking concentration), the World Bank (financial stability) and the International Country Risk Guide (a composite indicator of sovereign risk). 
Banking concentration is measured by the market share of the 5 largest banks in each country and is expected to affect negatively firm performance (Ratti et al., 2008), while bank credit provision is expected to exert a positive effect (Aghion et al., 2007; Bena and Jurajda, 2011). Financial stability is proxied by the z-score at country-level, where the higher the z-score, the lower the probability of insolvency of financial institutions, and the greater the stability of each country's financial system (Fielding and Rewilak, 2015). Sovereign risk is captured by (the inverse of) a composite index of sovereign risk consisting of political, economic and financial sub-indices. Thus, the greater the value of the edited composite index, the higher the sovereign risk of a country. Firm leverage is measured by the ratio of total debt to total assets, while the proxy for liquidity is the current ratio (current assets to current liabilities). For the post-crisis periphery countries we constructed a dummy that takes the value of 1 in the period 2009-2011 for firms located in Greece, Spain, Portugal, Slovenia, Italy, Ireland, Cyprus, and zero otherwise.

To estimate empirically the effect of our variables on firm growth we used a quantile dynamic panel methodology in order to account for heterogeneity and non-Gaussian distributions (Koenker, 2004), which are common when dealing with firm growth data. Our empirical model is an extension of the growth model introduced by Rajan and Zingales (1998) as adjusted at the firm level by Laeven and Valencia (2013). Hence, we estimate the following linear model for panel data formulated in matrix notation and quantile regression form:

$$
g_{i j, t}=\delta+x_{i j, t}^{\prime} \beta(q)+a_{i j}+u_{i j, t}
$$

where $g_{i j, t}$ denotes the growth rate of firm $i$ in country $j$ at time $t$. The parameters $\beta$ capture slope coefficients, $\alpha_{i j}$ are the fixed effects, $\delta$ is the constant term and $u_{i j, t}$ is the disturbance term. The matrix $x_{i j, t}^{\prime}=\left[F_{i j, t-1} C_{j, t}\right]$ comprises firm- and country-specific independent variables, while $q$ stands for the quantile $(0<q<1)$ of the conditional distribution. The vector $F$ encompasses firm-specific variables, like initial firm size, leverage and liquidity, lagged one year to take into account potential endogeneity issues. The vector $C$ contains country-specific variables, namely bank credit growth, banking concentration, financial stability, sovereign risk and location in the tumultuous post-crisis years.

\section{Results and discussion}

The results are presented in Table 1 for the two groups of micro and larger firms per (growth) quantile. Our basic findings reveal that micro firms are much more vulnerable and dependent on country characteristics than larger firms. Although we take into account separate variables for the structure of the local banking sector (concentration and financial stability) as well as the change in the provision of bank credit and the country risk, it is still found that micro firms located in the periphery of the euro area grow more slowly after 2009 (strong negative effect). This result is not surprising, but it is interesting to note that across quantiles the negative effect of the periphery dummy does not hold for super-fast growing micro firms (90\% quantile). In general, the fragmentation in growth conditions is significant for micro firms.

Particularly exposed are micro firms with slow-growth events (lower 10\% and 25\%), which are worse affected by increasing banking concentration and more exposed to financial stability and credit availability. Also, being located in the euro area periphery exerts a larger negative effect on their growth than on micro firms with faster growth events (50\% and 75\%), while the post-crisis periphery dummy does not hinder significantly the growth performance of superior growing micro firms (90\%).

Looking at larger firms we notice that banking structure variables and sovereign risk are mostly insignificant. A possible explanation could be that large firms may have access to more internationally diversified funds compared to their smaller counterparts. The post-crisis location 
of larger firms in periphery countries affects in a significant and negative way only the very slow growing firms (10\% quantile), while for all other quantiles of larger firms the periphery effect appears insignificant.

Regarding firm-level variables only liquidity facilitates significantly the growth of micro firms in the $25 \%$ quantile, while leverage obstructs significantly the growth of micro firms in the $10 \%$ quantile. Micro, less dynamic, firms prefer to hold their available liquidity rather than invest probably because of higher uncertainty. On the other hand, dynamic larger firms (upper $50 \%$ and $75 \%$ ) react to increased liquidity in the expected positive way.

Overall our main findings indicate that for micro firm growth the only significant determinants are the role of banking concentration and sovereign risk (negative), as well as financial stability (positive). On the other hand, firm growth of larger firms in the majority of quantile estimations seems not to be affected by financial stability or country risk, or even the location in the euro area periphery. Even so, a noticeable finding is that the determinants of 'universal' importance for firm growth across all size groups and quantiles are bank credit change and lagged firm sales.

As a robustness check we also performed complementary estimations by using crosssectional quantile regressions (Koenker and Basset, 1978) that ignore fixed effects. Although the parameter estimates appear to be in the same direction with those obtained from panel quantile regressions, the goodness of fit criterion as measured by the pseudo $\mathrm{R}^{2}$ favours the latter.

Despite the interesting results obtained from the empirical analysis, some data limitations can be identified. First, the available dataset used in this study focuses exclusively on quoted firms. Hence, a selection bias may appear since young small firms are usually underrepresented in a sample of listed firms. Second, the two size groups of firms examined are not equally populated (1767 micro firms vs. 308 larger firms), which in turn could have some implications for our empirical analysis.

\section{Concluding Remarks}

This paper explores the factors that impede micro firm growth using a quantile panel analysis on 2075 firms operating in the 17 countries of the euro area in 2005-2011. While larger firms are affected by the standard in the literature variables of bank credit growth and initial size, micro firms appear to be particularly vulnerable to country conditions such as location in the periphery of the euro area, banking concentration, financial stability and country risk. Such fragmentation in growth prospects should be taken into account when formulating policy interventions, much needed as a response to the euro area stagnation.

In this direction, the ongoing process of a European Banking Union is expected to improve financial stability, harmonize banking credit conditions and reduce sovereign risk. Also monetary policy easing by the ECB can be relied upon to facilitate credit provision. Especially the asset purchasing program $(\mathrm{QE})$ initiated more recently could be quite effective. Still, some extra support to peripheral locations would be instrumental in reducing fragmentation and enhancing micro firms. Facilitating their much needed growth and employment effects could reduce inequality and improve prospects in the euro area.

\section{References}

Aghion, P., Fally, T. and Scarpetta, S. (2007) Credit constraints as a barrier to the entry and post-entry growth of firms, Economic Policy, 22(52), 732-779.

Beck, T. and Demirgüç-Kunt, A. (2006) Small and medium-size enterprises: access to finance as a growth constraint, Journal of Banking and Finance, 30(11), 2931-2943. 
Bena, J. and Jurajda, S. (2011) Financial development and corporate growth in the EU single market, Economica, 78(311), 401-428.

Campello, M., Graham, J. and Harvey, C. (2010) The real effects of financial constraints: evidence from a financial crisis, Journal of Financial Economics, 97(3), 470-487.

Coad, A. and Tamvada J.P., (2012) Firm growth and barriers to growth among small firms in India, Small Business Economics, 39(2), 383-400.

ECB (2013) ECB monthly bulletin July 2013, European Central Bank: Frankfurt.

European Commission (2003) Commission recommendation of 6 May 2003 concerning the definition of micro, small and medium-sized enterprises, Official Journal of the European Union, 46, 36-41.

Fielding, D. and Rewilak, J. (2015) Credit booms, financial fragility and banking crises, Economics Letters, 136, 233-236.

Koenker, R. (2004) Quantile regression for longitudinal data, Journal Multivariate Analysis 91(1), 74-89.

Koenker, R., \& Bassett, G. (1978) Regression quantiles, Econometrica, 46(1), 33-50.

Laeven, L. and Valencia, F. (2013) The real effects of financial sector interventions during crises, Journal of Money, Credit and Banking, 45(1), 147-177.

Lee, N. (2014) What holds back high-growth firms? Evidence from UK SMEs, Small Business Economics, 43(1), 183-195.

Peric, M. and Vitezic, V. (2016) Impact of global economic crisis on firm growth, Small Business Economics, 46(1), 1-12.

Rajan, R. and Zingales, L. (1998) Financial dependence and growth, American Economic Review, 88(3), 559-586.

Ratti, R.A., Lee, S. and Seol, Y. (2008) Bank concentration and financial constraints on firmlevel investment in Europe, Journal of Banking and Finance, 32(12), 2684-2694. 
Table 1. Growth determinants of micro and larger firms in the euro area 2005-2011 - Panel quantile regressions.

\begin{tabular}{|c|c|c|c|c|c|c|c|c|c|c|}
\hline & \multicolumn{5}{|c|}{ Micro Firms } & \multicolumn{5}{|c|}{ Larger Firms } \\
\hline & $10 \%$ & $25 \%$ & $50 \%$ & $75 \%$ & $90 \%$ & $10 \%$ & $25 \%$ & $50 \%$ & $75 \%$ & $90 \%$ \\
\hline $\begin{array}{l}\text { Banking } \\
\text { Concentration } \\
\text { (CR5) }\end{array}$ & $\begin{array}{c}-0.18647 * * * \\
(0.04767)\end{array}$ & $\begin{array}{c}-0.06473 * * * \\
(0.01923)\end{array}$ & $\begin{array}{c}-0.04439 * * * \\
(0.01436)\end{array}$ & $\begin{array}{l}-0.01762 \\
(0.02406)\end{array}$ & $\begin{array}{c}0.12875^{* *} \\
(0.0607)\end{array}$ & $\begin{array}{c}-0.16782^{* * * *} \\
(0.06087)\end{array}$ & $\begin{array}{c}-0.05217 * * \\
(0.0238)\end{array}$ & $\begin{array}{l}-0.0311^{*} \\
(0.0189)\end{array}$ & $\begin{array}{c}-0.0484 \\
(0.03208)\end{array}$ & $\begin{array}{c}-0.0667 \\
(0.06662)\end{array}$ \\
\hline $\begin{array}{l}\text { Financial Stability } \\
\text { (Z-score) }\end{array}$ & $\begin{array}{c}0.00459 * * * \\
(0.0011)\end{array}$ & $\begin{array}{l}0.00259 * * * \\
(0.00047)\end{array}$ & $\begin{array}{c}0.00133 * * * \\
(0.00035)\end{array}$ & $\begin{array}{l}0.0009 * \\
(0.00055)\end{array}$ & $\begin{array}{c}0.00137 \\
(0.00143)\end{array}$ & $\begin{array}{l}-0.00183 \\
(0.00125)\end{array}$ & $\begin{array}{l}-0.00064 \\
(0.00063)\end{array}$ & $\begin{array}{c}0.00077 \\
(0.00057)\end{array}$ & $\begin{array}{c}0.00037 \\
(0.00093)\end{array}$ & $\begin{array}{l}0.004 * * \\
(0.00171)\end{array}$ \\
\hline Sovereign Risk & $\begin{array}{l}-0.25709 \\
(0.20123)\end{array}$ & $\begin{array}{l}-0.15517 * * \\
(0.07738)\end{array}$ & $\begin{array}{c}-0.21306 * * * \\
(0.06535)\end{array}$ & $\begin{array}{c}-0.46663 * * * \\
(0.09758)\end{array}$ & $\begin{array}{c}-0.838 * * * \\
(0.2276)\end{array}$ & $\begin{array}{c}0.26978 \\
(0.20192)\end{array}$ & $\begin{array}{l}-0.00251 \\
(0.11059)\end{array}$ & $\begin{array}{l}0.00555 \\
(0.0949)\end{array}$ & $\begin{array}{c}0.08037 \\
(0.14977)\end{array}$ & $\begin{array}{l}-0.18178 \\
(0.25178)\end{array}$ \\
\hline $\begin{array}{l}\text { Bank Credit } \\
\text { (\%Change) }\end{array}$ & $\begin{array}{c}0.67568 * * * \\
(0.06296)\end{array}$ & $\begin{array}{l}0.35724 * * * \\
(0.0302)\end{array}$ & $\begin{array}{l}0.2096 * * * \\
(0.03088)\end{array}$ & $\begin{array}{c}0.19754 * * * \\
(0.05154)\end{array}$ & $\begin{array}{c}0.31375 * * * \\
(0.09774)\end{array}$ & $\begin{array}{c}0.76946 * * * \\
(0.11226)\end{array}$ & $\begin{array}{c}0.52722 * * * \\
(0.05738)\end{array}$ & $\begin{array}{c}0.38293 * * * \\
(0.07151)\end{array}$ & $\begin{array}{c}0.46586 * * * \\
(0.10973)\end{array}$ & $\begin{array}{l}0.3703 * * \\
(0.15552)\end{array}$ \\
\hline $\begin{array}{l}\text { Post-Crisis Periph- } \\
\text { ery }\end{array}$ & $\begin{array}{c}-0.12362 * * * \\
(0.02719)\end{array}$ & $\begin{array}{l}-0.07307 * * * \\
(0.01085)\end{array}$ & $\begin{array}{c}-0.04857^{* * * *} \\
(0.00566)\end{array}$ & $\begin{array}{c}-0.02272 * * \\
(0.00925)\end{array}$ & $\begin{array}{l}0.04276 \\
(0.03113)\end{array}$ & $\begin{array}{c}-0.07259 * * * \\
(0.02774)\end{array}$ & $\begin{array}{l}-0.00948 \\
(0.02025)\end{array}$ & $\begin{array}{c}0.00502 \\
(0.01477)\end{array}$ & $\begin{array}{l}-0.00672 \\
(0.01603)\end{array}$ & $\begin{array}{c}0.01634 \\
(0.02495)\end{array}$ \\
\hline Firm Liquidity & $\begin{array}{l}-0.00513 \\
(0.00642)\end{array}$ & $\begin{array}{l}-0.00387 * * * \\
(0.00111)\end{array}$ & $\begin{array}{l}-0.00092 \\
(0.00268)\end{array}$ & $\begin{array}{c}0.00205 \\
(0.00601)\end{array}$ & $\begin{array}{c}0.01993 \\
(0.01737)\end{array}$ & $\begin{array}{l}-0.03601 \\
(0.02458)\end{array}$ & $\begin{array}{l}-0.01624 \\
(0.0102)\end{array}$ & $\begin{array}{c}0.0132 * \\
(0.00808)\end{array}$ & $\begin{array}{l}0.02367 * \\
(0.0124)\end{array}$ & $\begin{array}{c}0.01547 \\
(0.01664)\end{array}$ \\
\hline Firm Leverage & $\begin{array}{l}-0.01668^{*} \\
(0.00903)\end{array}$ & $\begin{array}{c}-0.00015 \\
(0.00271)\end{array}$ & $\begin{array}{l}-0.00027 \\
(0.0002)\end{array}$ & $\begin{array}{l}-0.00003 \\
(0.00027)\end{array}$ & $\begin{array}{c}0.00097 \\
(0.01)\end{array}$ & $\begin{array}{l}-0.00023 \\
(0.08062)\end{array}$ & $\begin{array}{l}-0.00053 \\
(0.00626)\end{array}$ & $\begin{array}{l}-0.00072 \\
(0.00115)\end{array}$ & $\begin{array}{l}-0.00111 \\
(0.00443)\end{array}$ & $\begin{array}{l}-0.00078 \\
(0.04548)\end{array}$ \\
\hline Firm Sales & $\begin{array}{c}0.03216 * * * \\
(0.00496)\end{array}$ & $\begin{array}{l}0.00756 * * * \\
(0.00219)\end{array}$ & $\begin{array}{c}-0.00303 * * \\
(0.00146)\end{array}$ & $\begin{array}{c}-0.02132 * * * \\
(0.0027)\end{array}$ & $\begin{array}{c}-0.06666 * * * \\
(0.00663)\end{array}$ & $\begin{array}{c}-0.02424 * * * \\
(0.00822)\end{array}$ & $\begin{array}{c}-0.01349 * * * \\
(0.00475)\end{array}$ & $\begin{array}{c}-0.00789 * * \\
(0.0032)\end{array}$ & $\begin{array}{c}-0.01517 * * * \\
(0.0058)\end{array}$ & $\begin{array}{c}-0.03202 * * * \\
(0.0088)\end{array}$ \\
\hline Constant term & $\begin{array}{c}-0.52269 * * * \\
(0.07208)\end{array}$ & $\begin{array}{l}-0.1323 * * * \\
(0.03138)\end{array}$ & $\begin{array}{c}0.10605 * * * \\
(0.02214)\end{array}$ & $\begin{array}{c}0.46961 * * * \\
(0.0448)\end{array}$ & $\begin{array}{c}1.14346 * * * \\
(0.10937)\end{array}$ & $\begin{array}{c}0.33927 * * \\
(0.14469)\end{array}$ & $\begin{array}{c}0.22258 * * \\
(0.08831)\end{array}$ & $\begin{array}{c}0.13937 * * \\
(0.06261)\end{array}$ & $\begin{array}{c}0.3173 * * * \\
(0.10781)\end{array}$ & $\begin{array}{l}0.7159 * * * \\
(0.16255)\end{array}$ \\
\hline Pseudo-R ${ }^{2}$ & 0.09533 & 0.09815 & 0.10296 & 0.10788 & 0.11089 & 0.04431 & 0.03767 & 0.02610 & 0.01388 & 0.00622 \\
\hline No of observations & 9843 & 9843 & 9843 & 9843 & 9843 & 1867 & 1867 & 1867 & 1867 & 1867 \\
\hline
\end{tabular}

Notes: *The null hypothesis that each coefficient is equal to zero is rejected at the $10 \%$ level of significance.**The null hypothesis that each coefficient is equal to zero is rejected at the $5 \%$ level of significance. $* * *$ The null hypothesis that each coefficient is equal to zero is rejected at the $1 \%$ level of significance. Bootstrap standard errors are reported in parentheses. 
Table 2. Growth determinants of micro and larger firms in the euro area 2005-2011 - Pooled quantile regressions.

\begin{tabular}{|c|c|c|c|c|c|c|c|c|c|c|}
\hline & \multicolumn{5}{|c|}{ Micro Firms } & \multicolumn{5}{|c|}{ Larger Firms } \\
\hline & $10 \%$ & $25 \%$ & $50 \%$ & $75 \%$ & $90 \%$ & $10 \%$ & $25 \%$ & $50 \%$ & $75 \%$ & $90 \%$ \\
\hline $\begin{array}{l}\text { Banking } \\
\text { Concentration } \\
\text { (CR5) }\end{array}$ & $\begin{array}{c}-0.18751 * * * \\
(0.04458)\end{array}$ & $\begin{array}{c}-0.05622^{* * *} \\
(0.01879)\end{array}$ & $\begin{array}{c}-0.04155^{* * * *} \\
(0.01307)\end{array}$ & $\begin{array}{l}-0.01200 \\
(0.01827)\end{array}$ & $\begin{array}{c}0.14398 * * \\
(0.05822)\end{array}$ & $\begin{array}{l}-0.15464 * \\
(0.08356)\end{array}$ & $\begin{array}{c}-0.06529 * * * \\
(0.02082)\end{array}$ & $\begin{array}{c}-0.03488^{* * *} \\
(0.01247)\end{array}$ & $\begin{array}{c}-0.05411 * * \\
(0.02315)\end{array}$ & $\begin{array}{l}-0.08157 \\
(0.07395)\end{array}$ \\
\hline $\begin{array}{l}\text { Financial Stabil- } \\
\text { ity } \\
\text { (Z-score) }\end{array}$ & $\begin{array}{c}0.00473 * * * \\
(0.0011)\end{array}$ & $\begin{array}{c}0.00249 * * * \\
(0.00029)\end{array}$ & $\begin{array}{c}0.00138^{* * *} \\
(0.00033)\end{array}$ & $\begin{array}{l}0.00079 * \\
(0.00047)\end{array}$ & $\begin{array}{c}0.00111 \\
(0.00113)\end{array}$ & $\begin{array}{c}-.00134 \\
(0.00158)\end{array}$ & $\begin{array}{c}-.00054 \\
(0.00076)\end{array}$ & $\begin{array}{l}.00091 * * \\
(0.00042)\end{array}$ & $\begin{array}{c}.00075 \\
(0.00092)\end{array}$ & $\begin{array}{c}.00393 * \\
(0.00204)\end{array}$ \\
\hline Sovereign Risk & $\begin{array}{l}-0.21855 \\
(0.17440)\end{array}$ & $\begin{array}{l}-0.07965 \\
(0.05538)\end{array}$ & $\begin{array}{c}-0.14674 * * * \\
(0.04182)\end{array}$ & $\begin{array}{c}-0.42055^{* * * *} \\
(0.07332)\end{array}$ & $\begin{array}{c}-0.77973 * * * \\
(0.23361)\end{array}$ & $\begin{array}{c}.14329 \\
(0.25589)\end{array}$ & $\begin{array}{c}-.02379 \\
(0.11168)\end{array}$ & $\begin{array}{c}-.00088 \\
(0.08656)\end{array}$ & $\begin{array}{c}.06462 \\
(0.10571)\end{array}$ & $\begin{array}{c}-.16844 \\
(0.30422)\end{array}$ \\
\hline $\begin{array}{l}\text { Bank Credit } \\
\text { (\%Change) }\end{array}$ & $\begin{array}{c}0.69034 * * * \\
(0.07562)\end{array}$ & $\begin{array}{c}0.35344 * * * \\
(0.03041)\end{array}$ & $\begin{array}{c}0.22195^{* * *} \\
(0.03495)\end{array}$ & $\begin{array}{c}0.23349 * * * \\
(0.05185)\end{array}$ & $\begin{array}{c}0.33662 * * * \\
(0.12999)\end{array}$ & $\begin{array}{c}.73876 * * * \\
(0.14841)\end{array}$ & $\begin{array}{l}.52536 * * * \\
(0.07431)\end{array}$ & $\begin{array}{l}.36809 * * * \\
(0.07244)\end{array}$ & $\begin{array}{l}.45831 * * * \\
(0.07438)\end{array}$ & $\begin{array}{l}.35404 * * * \\
(0.10419)\end{array}$ \\
\hline $\begin{array}{l}\text { Post-Crisis Pe- } \\
\text { riphery }\end{array}$ & $\begin{array}{c}-0.12414 * * * \\
(0.03064)\end{array}$ & $\begin{array}{c}-.07710^{* * *} \\
(0.01194)\end{array}$ & $\begin{array}{c}-0.04836 * * * \\
(0.00578)\end{array}$ & $\begin{array}{c}-0.02049 * * * \\
(0.00702)\end{array}$ & $\begin{array}{c}0.04513 \\
(0.03195)\end{array}$ & $\begin{array}{c}-.06766^{* *} \\
(0.03323)\end{array}$ & $\begin{array}{l}-0.01226 \\
(0.02292)\end{array}$ & $\begin{array}{c}0.00243 \\
(0.01656)\end{array}$ & $\begin{array}{l}-0.00879 \\
(0.01312)\end{array}$ & $\begin{array}{c}0.01275 \\
(0.02811)\end{array}$ \\
\hline Firm Liquidity & $\begin{array}{l}-0.00504 \\
(0.00522)\end{array}$ & $\begin{array}{c}-0.00383^{* * *} \\
(0.00105)\end{array}$ & $\begin{array}{l}-0.00095 \\
(0.00296)\end{array}$ & $\begin{array}{c}0.00245 \\
(0.00587)\end{array}$ & $\begin{array}{c}0.02036 \\
(0.02031)\end{array}$ & $\begin{array}{l}-0.03808 \\
(0.02820)\end{array}$ & $\begin{array}{l}-0.01560 * \\
(0.00941)\end{array}$ & $\begin{array}{c}0.01437 * * \\
(0.00708)\end{array}$ & $\begin{array}{l}0.02738 * \\
(0.01466)\end{array}$ & $\begin{array}{c}0.01818 \\
(0.01458)\end{array}$ \\
\hline Firm Leverage & $\begin{array}{l}-0.01668 \\
(0.01146)\end{array}$ & $\begin{array}{l}-0.00015 \\
(0.00055)\end{array}$ & $\begin{array}{l}-0.00027 \\
(0.00023)\end{array}$ & $\begin{array}{l}-0.00002 \\
(0.00028)\end{array}$ & $\begin{array}{c}0.00088 \\
(0.01121)\end{array}$ & $\begin{array}{l}-0.00015 \\
(0.11284)\end{array}$ & $\begin{array}{l}-0.00049 \\
(0.00520)\end{array}$ & $\begin{array}{l}-0.00070 \\
(0.00190)\end{array}$ & $\begin{array}{l}-0.00107 \\
(0.00121)\end{array}$ & $\begin{array}{l}-0.00010 \\
(0.01067)\end{array}$ \\
\hline Firm Sales & $\begin{array}{c}0.031576^{* * *} \\
(0.00347)\end{array}$ & $\begin{array}{c}0.00813 * * * \\
(0.00147)\end{array}$ & $\begin{array}{c}-0.00299 * * \\
(0.00132)\end{array}$ & $\begin{array}{c}-0.02065^{* * *} \\
(0.00172)\end{array}$ & $\begin{array}{c}-0.06660 * * * \\
(0.00443)\end{array}$ & $\begin{array}{c}-0.02601 * * * \\
(0.00756)\end{array}$ & $\begin{array}{c}-0.01444^{* * *} \\
(0.00398)\end{array}$ & $\begin{array}{c}-0.00820^{* * *} \\
(0.00268)\end{array}$ & $\begin{array}{c}-0.01483^{* * *} \\
(0.00557)\end{array}$ & $\begin{array}{c}-0.03164 * * * \\
(0.00839)\end{array}$ \\
\hline Constant term & $\begin{array}{c}-0.51240 * * * \\
(0.06409)\end{array}$ & $\begin{array}{c}-0.14511^{* * *} \\
(0.02205)\end{array}$ & $\begin{array}{c}0.10133^{* * *} \\
(0.01988)\end{array}$ & $\begin{array}{c}0.46054 * * * \\
(0.03022)\end{array}$ & $\begin{array}{l}1.1358 * * * \\
(0.09788)\end{array}$ & $\begin{array}{c}0.37989 * * * \\
(0.11549)\end{array}$ & $\begin{array}{c}0.23995^{* * *} \\
(0.07400)\end{array}$ & $\begin{array}{c}0.14034 * * * \\
(0.05139)\end{array}$ & $\begin{array}{c}0.30316^{* * *} \\
(0.10030)\end{array}$ & $\begin{array}{c}0.70678 * * * \\
(0.14324)\end{array}$ \\
\hline Pseudo- $\mathrm{R}^{2}$ & 0.0450 & 0.0282 & 0.0160 & 0.0194 & 0.0425 & 0.0512 & 0.0320 & 0.0244 & 0.0280 & 0.0414 \\
\hline $\begin{array}{l}\text { No of observa- } \\
\text { tions }\end{array}$ & 9843 & 9843 & 9843 & 9843 & 9843 & 1867 & 1867 & 1867 & 1867 & 1867 \\
\hline
\end{tabular}

